\title{
Renewable Energy Transition: A Panacea to the Ravaging Effects of Climate Change in Nigeria
}

\author{
Usman Bello1,2*, Livingstone Udofia ${ }^{3}$, Olayinka A. Ibitowa ${ }^{4}$, Auwal M. Abdullahi'5, \\ Ibrahim Sulaiman', Khuzaifah M. Yahuza' ${ }^{1}$ \\ ${ }^{1}$ Department of Chemistry, Abubakar Tafawa Balewa University, Bauchi, Nigeria \\ ${ }^{2}$ Department of Chemical Engineering, Universiti Teknologi PETRONAS, Malaysia \\ ${ }^{3}$ Institute of Chemistry, Otto Von Guericke Universität Magdeburg, Germany \\ ${ }^{4}$ Institute of Chemistry, Carl Von Ossietzky Universität Oldenburg, Germany \\ ${ }^{5}$ Department of Chemistry, Bayero University Kano, Nigeria \\ ${ }^{6}$ Department of History, Bayero University Kano, Nigeria \\ Email: *usmanbello088@gmail.com
}

How to cite this paper: Bello, U., Udofia, L., Ibitowa, O. A., Abdullahi, A. M., Sulaiman, I., \& Yahuza, K. M. (2021). Renewable Energy Transition: A Panacea to the Ravaging Effects of Climate Change in Nigeria. Journal of Geoscience and Environment Protection, 9, 151-167.

https://doi.org/10.4236/gep.2021.912010

Received: November 10, 2021

Accepted: December 26, 2021

Published: December 29, 2021

Copyright $\odot 2021$ by author(s) and Scientific Research Publishing Inc. This work is licensed under the Creative Commons Attribution International License (CC BY 4.0).

http://creativecommons.org/licenses/by/4.0/

\begin{abstract}
Environmental issues linked to climate change and global warming have been at the centre stage of discussion all over the world, considering their magnitude and the broader scope of consequences. These catastrophic effects of greenhouse gases (GHG) such as $\mathrm{CO}_{2}$, $\mathrm{CO}$, water vapour, nitrous oxides, ozone, coupled with other artificially induced chemicals like CFCs have shifted weather patterns across the globe, thereby threatening the environment unpleasantly. However, the effects of climate changes are more pronounced in Nigeria, due to an unprecedented utilization of fossil-based fuels as the main energy source for electricity, transportation, industrial, agricultural, and domestic purposes. As a result, air pollution and land spills by oil led to the destruction of agricultural land and increasing heatwaves were left behind. Consequently, these impacted negatively on the ecosystem by intimidating the environment, counteracting biodiversity, decelerating economy and provoking human comfort, while simultaneously antagonizing socio-economic growth and sustainable developments. Thus, an urgent need for the Nigerian government to redirect from fossil fuels to renewables and intensify the campaign for afforestation to support green conservation of biodiversity. These are considered plausible measures for remediating the lingering energy failure and ravaging effects of climate change. Therefore, this short review of communications $\mathrm{X}$-rayed a few of the recent devasting incidences caused by climate change, their impacts on various sectors of the economy and the need to explore renewable energy resources in the country as a tool to finding solutions to the effects of climate changes and global warming.
\end{abstract}




\section{Keywords}

Renewable Energy, Environment, Climate Change, Global Warming, and Sustainable Developments

\section{Introduction}

The present and predicted emissions of GHG, pose greater threats to the well-being of mankind and the environment for today and tomorrow at both local, regional, and global levels (Adamu et al., 2021). As an emerging challenged, energy and environment are key concerns of governments globally and hence categorized among the United Nations Sustainable Development Goals (SDGs), (Goal 7: Affordable and Clean Energy, and Goal 13: Climate Action). According to Adewuyi et al. (2020) achieving the goal of having affordable and clean energy, will lead to the accomplishments of all other sustainable developments goals. In the light of this, clean energy development is a key to attainments of climate secured atmosphere, in a manner to cut down GHG emissions, foster ecologically friendly sphere, support energy transition mechanism and enhanced energy security, thereby reducing energy dependence on imported crude oil. Simultaneously, these would promote an eco-friendly environment, enhance sustainable growth, and improve socio-economic developments. While on the other hand, failure to tackle the effect of climate change could disrupt UN SDGs (1 and 2), achieving no poverty and zero hunger because of the impacts on agriculture and food security (Abdulkadir et al., 2018).

Looking at the causes, emissions emanating from burning fossil fuels were identified as the foremost drivers for the uprising crisis of climate change and biodiversity (Agarwal, 2007), which distort the weather conditions and foster socio-economic destruction. Accordingly, it has been established that the African region is the least contributor to GHG emissions but the most deadly affected by the impacts of climate change (Ofosu-Peasah et al., 2021). Therefore, these ever-growing consequences of climate change were occasioned with the predominant burning of fossil-based fuels such as coal, natural gas, and petroleum, as well as their by-products like petrol, kerosene, and diesel as the main source of energy for domestic, industrial, transport and agricultural purposes (Sandu et al., 2019). They spontaneously accelerate $\mathrm{CO}_{2}$ emissions, a factor believed to be responsible for the heightened global warming (Haider, 2019). Unfortunately, Nigeria and other Sub-Saharan African countries appear to lack adequate skilled human resources and technical know-how for innovations, to explore the abundant renewable energy resources in the region. In the light of this, there is a need to redirect strategies, to effectively navigate this challenging energy thirst and lessen the magnitude of GHG that metamorphosed to the rising climatic changes in Africa (Oyedepo, 2014). Hence, this short communication highlights the potentials of renewable energy resources in Nigeria that were 
left unexploited, and the need for exploration of these resources towards proffering solutions to the ravaging effects of climate induced impacts that circumscribed prosperous economic growth and sustainable developments.

\section{Nigerian Scenario}

In this context, it is an undisputed fact that Nigeria is endowed with plenty of natural resources including fossil fuels and renewable energies, but surprisingly the renewable energy resources were left untapped (Oyedepo, 2012). However, nature being made part of the environment is our life-supporting system, in which natural systems provide so many essentials like water, clean air, fertile soils, and a stable climate, which directly underpin our socio-economic wellbeing. Unfortunately, excessive exploitation of fossil fuels, exploration, production, and combustion, placed these natural systems under greater stress, which in turn exposed our environment and economy to growing nature-related risks that we are all feeling the pinch (Oji \& Adamu, 2021). With the pace we are going, the earth is under threats of both natural and human-induced catastrophes heightened by technology (Coster \& Adeoti, 2015). Consequently, these grievous effects of intense climate changes saw the Paris agreement of 2015, where more than sixty countries agreed to cut down the use of fossil fuels (IRENA, 2019). Therefore, minimizing the effects of climate change can be upended by bringing down carbon footprint to net-zero emissions by 2050 (Latif et al., 2021). Accordingly, these decarbonization policies prompted the paradigm shift from fossil fuel to renewables, in a bid to limit the extreme weather and climate impacts poised by the bulk GHG emissions while simultaneously ensuring clean, sustainable energy and climate-friendly environment in line with SDGs requirements (Mofijur et al., 2019).

While sustainable development demands an efficient, reliable, and decentralized energy economy, based on local and clean energy sources, renewable energy is rapidly embraced as an essential source of energy in many regions and countries across the world as it provides a dual solution to energy and environmental crisis in a sustainable, economically viable and eco-friendly manner (Vine, 2008). Energy is critical to the economic, social, and political development of every nation, and is often regarded as an index of rating the level of urbanization, industrialization, and advancement. Thus, tackling energy poverty is a key to achieving socio-economic and sustainable development. While on the other hand energy, the deficit is seen as a roadblock that inhibits economic growth, development and jeopardized the future of the younger generation (Oseni, 2011). Thus, it became imperative for the Nigerian government to take advantage of the current revenue influx from the oil and gas sector to develop renewable energy technology by implementing the country's Renewable Master Plan of 2005, 2006 and equally intensify efforts on the diversification policy and strategies towards meeting their energy demand, and to sustain prosperous development in all sectors within these dynamics of a competitive global economy. 


\subsection{Impacts of Climate Change in Nigeria}

Towards achieving the global target for a maximum temperature of $1.5^{\circ} \mathrm{C}$, all hands must be on deck concerning emissions avoidance, rebranding mitigation strategies, and evidence-based environmental policies, while embracing renewable energy technology as the plausible option to achieving the outlined objectives. Nigeria, being the most populated country in Africa, with a population of over 212.59 billion people (Statista, 2021), is poised to take the lead in tackling the menace of climate change but sadly is the most vulnerable due to low precipitation leading to drought and desertification in the north; high precipitation in the south that is peculiar with flooding and erosion (Akande et al., 2017), as well as flared gases and oil spillage precisely from the Niger Delta region of the country (Shaaban \& Petinrin, 2014). According to vulnerability analysis reported by Onah et al. (2016) revealed that the northern part of Nigeria is more vulnerable to climate change compared to the southern part due to the nature of the geographical zone which is lying on the Savannah belt. This made the country one of the top contributors to GHG emissions with about $1.01 \%$ of the total global emissions (Okonkwo et al., 2021). No doubt, fossil fuel exploitation, and production in Nigeria is seen as a blessing, by putting up economic growth and drove developments of the country relatively from the revenues generated, but can also be seen on the other hand as a curse especially now that the adverse effects of oil spillage and hazardous emissions are impacting negatively on the ecosystem (Kailasam, 2006), leaving behind legacies such as gas flaring, tense climatic conditions with rising heatwaves and reclamation of land due to oil and gas extraction, were unhealthy to the environment. Accordingly, these heightened GHG emissions and contributes to global warming (Tick Hui et al., 2018). Thus, the combustion of fossil fuels is linearly correlated to the increasing concentrations of GHG, which subsequently gave rise to the earth's climatic changes (Nicholls, 2004).

The evidence of climate changes in Nigeria has manifested a long time ago (Okundamiya et al., 2014), and this is clearly visible in sectors such as agriculture, economy, power, and energy. For instance, in July 2021, states like Jigawa, Kebbi, Bauchi, and Sokoto have witnessed devasting incidences of flooding, in which many lives were lost, people displaced, farmlands washed away, and billions of properties destroyed (Climate Change, 2021). The scenes of some recent destructions, truncating roads, flooded residential areas, and burning farm produce caused by the abrupt seizure of rainfall in Bauchi state, northern Nigeria is depicted in Figure 1. Consequently, these jeopardize the socio-economic welfare of the people in the affected states, their neighbouring towns and ultimately affect the food supply chain, close market breath, and make life very difficult (Efe \& Weli, 2015). Many of these climate changes frustrated agricultural activities and made farming impossible for many average farmers. Much alarming is the fact that more than $70 \%$ of Nigerians are surviving below the poverty line and relying on agriculture as their main source of income, unfortunately, the advent 


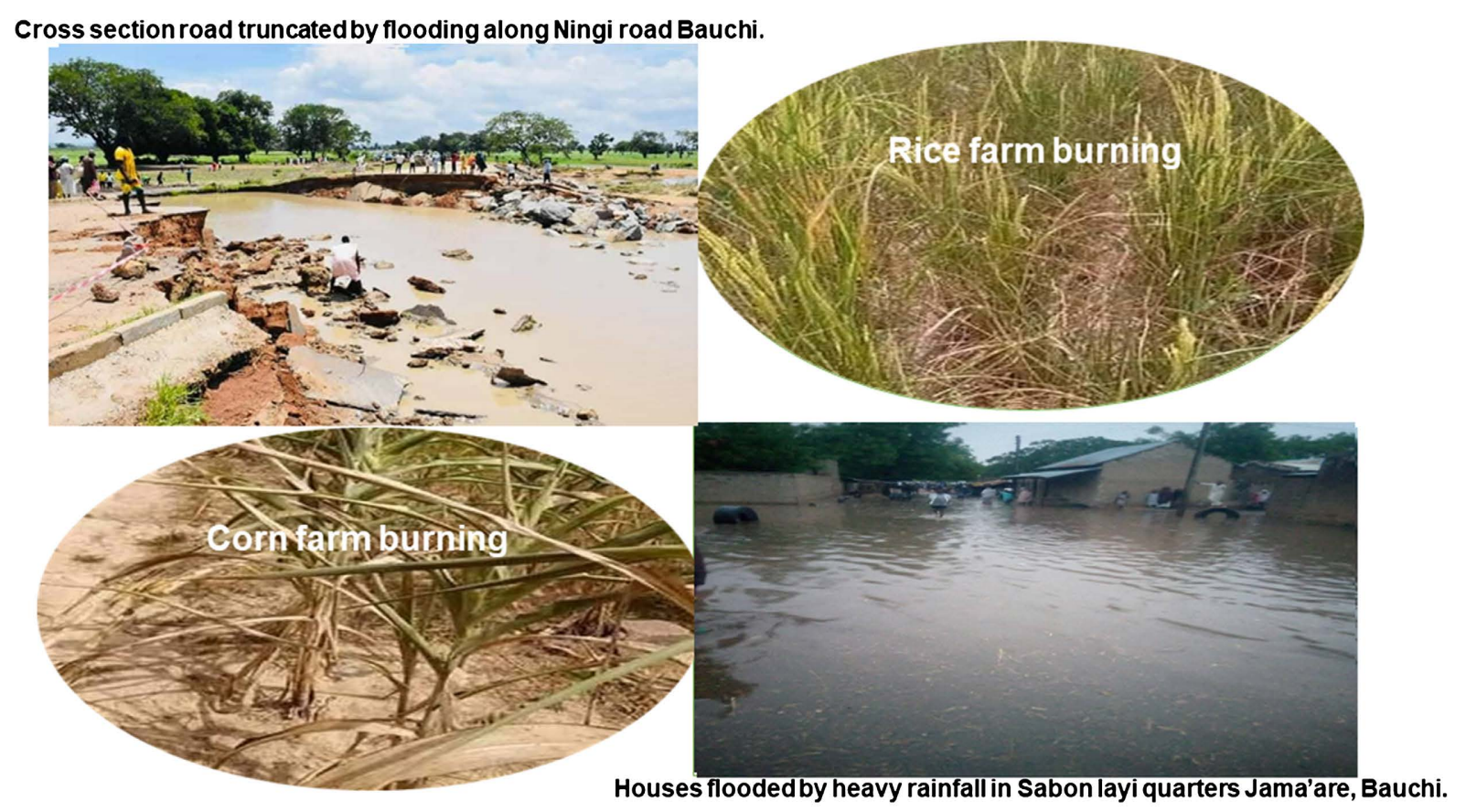

Figure 1. Scenes of some recent destruction caused by flooding and abrupt seizure of rainfall in Bauchi state, northern Nigeria.

of drought and flooding made thousands of farmers abandon their farmlands. According to World Bank, consequences of climate change in Nigeria such as rising temperatures, flooding, and seizure of rainfall in some places, could lead to a $20 \%$ to $30 \%$ reduction in crop yields. Recently, dust storms are equally becoming more common in northern Nigeria, which can significantly deplete topsoil layers and hinder successful farming. This will lead to food shortage, accelerate poverty and hunger, thereby aggravating the level of insecurity in the country (Ebele \& Emodi, 2016). In the same vein, more than half of the Nigerian population are said to be vulnerable to the effects of climate change (Idowu et al., 2011), since most communities are grapple with issues of basic human needs and rights such as lack of access to education, healthcare, stable electricity, clean water, and sustainable developments. Therefore, effective climate-smart agriculture, pollution prevention, and GHG emission avoidance, community education, and partnership for sustainable development are requisites to mitigating the impacts of global warming and climate change.

\subsection{Impacts on the Economy}

In Nigeria, the impacts of climate changes are hitting hard in virtually all sectors of the economy (Haider, 2019) and these can be buttressed by the incessant rise in the prices of goods and services by about $100 \%$ to $200 \%$ depending on the goods or services. However, farming and rearing are said to be the main source of obtaining livelihood for most of the Nigerian population, the climate change affects the economy with a visible impact ranging from a decline in farm produce, susceptibility to illness due to weak immune system and high rate of mor- 
tality among women and children (Ebele \& Emodi, 2016). According to Dinar et al. (2012) Nigeria like other African countries whose economies largely depend on weather-sensitive agricultural production systems, are particularly prone to climate change. Unfortunately, lack of workable policy for the adoption of sustainable land management practices such as agroforestry, climate-smart agriculture, and conservation for improved yields to enhance farmers' resilience to climate variability, affected agricultural productivity. Moreover, poor irrigation systems, inadequate modern cropping techniques, insufficient improved variety of seedlings coupled with unstable power supply, and high prices of fuel, forced out many average farmers from dry season farming (Akuru \& Okoro, 2010), a factor believed to have serious consequences on the economy, especially to the rural dwellers. Similarly, the power sector equally has its own share of consequences arising from climate change impacts, because the hydropower plants and power transmission lines used for electricity generation and distributions respectively, are susceptible to being destroyed by heavy flooding. A scenario believed to aggravate the epileptic power supply in Nigeria, and further identified as a factor that affected the ease of doing business in the country over the last two decades (Nwankwoala, 2012). This prompted many entrepreneurs to fall back on the use of powered generators to augment the national grid (Okundamiya et al., 2014), which subsequently reflects on the prices of goods and services. Thus, climate change is analogous to poverty such that when people become destitute, they find it difficult to adapt to certain conditions due to lack of resources, mobility, and shelter, as a result, they are set off susceptible to poverty and hunger.

\subsection{Impacts on the Ecology}

The environmental constraint is one of the main factors inhibiting the green growth in Nigerian, which was said to have affected the attainment of else-while country's vision 2020 (Okonkwo et al., 2021). In the northern part of the country the desert encroachment is mainly caused by the combination of rising heat and less rain, loss of the wetlands, and fast reduction in the amount of surface water, flora, and fauna resources on land (Abdulkadir et al., 2018), whereas other coastal areas are battling with rising sea levels and flooding (Coster \& Adeoti, 2015). Coming down to the southern part, where most of the cities are jammed with large people fill up in a very small area, surrounded by slums, are often vulnerable to flooding due to rising sea levels. As a result, most inland areas were occupied with refugees from the coastal zones who are forced out by flooding and related natural disasters (Akande et al., 2017). On top of that, climate change leads to an increase in relative humidity and temperature, thereby providing a hub for diseases to thrive while the abrupt seizure of rainfall and hydrological cycle sequence, shortening yield and affecting the entire productivity (Shaaban \& Petinrin, 2014). Moreover, increasing temperatures and changes in rainfall patterns, severely affect agricultural yields of both rainfed and irrigated 
crops while the uncurbed rise of sea levels leads to the loss of land, landscape, and infrastructure. Generally, the importance of the agricultural sector to livelihoods and the economy cannot be overemphasized since issues affecting crop yields and productivity can have an adverse effect on gross domestic product (Eleri et al., 2013). While other ravaging effects of climates particularly flooding can compromise economic growth through a reduction in production and infrastructure losses. increasing the frequency of droughts will distort hydropower production, thereby forestalling electricity generation. Thus, the need for more investment in climate-smart agriculture and physical infrastructure to mute climate variability.

According to Qurashi et al. (2005), the liberation of emissions from combustion engines and diesel generators, affects the quality of air, water, climate, land, and wildlife, through particulate and gaseous emissions, which in turn increase the levels of harmful radiations and atmospheric pollution (Abali et al., 2018). These emissions, accelerate the depletion of the ozone layer and subsequently contributes to global warming and climatic changes (Coster \& Adeoti, 2015). Also, the $\mathrm{CO}_{2}$ emissions released from power plants and petrochemical industries, are fatal to man and his environment (Abali et al., 2018). Moreover, excessive exploitation of crude oil led to the release of several toxic substances, such as benzene and polycyclic aromatic hydrocarbon (Ngene et al., 2016), thereby posing a serious threat to public health and the environment. Furthermore, pollution caused by oil spillage on land often contaminates exhaust soil nutrients and destroyed farmlands, a scenario that hindered farming activities. Whereas spills on water affect the aquatic organism by depleting dissolved oxygen in the water and thus make them difficult to survive (Chikwe \& Ogbole, 2019). These limited agricultural practices and caused substantial economic loss, accelerated poverty, hunger, insecurity, and hibernate socioeconomic progress (Obiakalaije et al., 2015). Therefore, more productive, and climate-resilient agriculture, cheaper and more geographically balanced power generation, efficient use of the country's endowment of oil and gas resources, and better provision of mass transport services, resulting in improved air quality and lower congestion are needed to drive sustainable growth and development.

\subsection{Impacts on Energy Security}

Way back in 2017, it has been reported that about 1.1 billion people globally were said to have no access to clean energy and a healthy environment (Lee \& Callaway, 2018). However, the issue is more severe in the sub-Saharan African region where only one out three of its population are having access to affordable and clean energy, with the very small proportion that is connected to the grid, experiencing unreliable services that short-change their daily energy need (Meyer et al., 2018). This could be attributed to the monopoly in the energy sector, resulting in mass-energy disparity and huge energy poverty. As a result, most houses, businesses, and government establishments are running on diesel 
or gasoline generators or using direct biomass for cooking and heating purposes. A scenario that impacts negatively on the immediate environment by contributing to the accumulation of GHG and is fatal to human health (Vidadili et al., 2017). Putting Nigeria on the table, where there is an abundance of crude oil and gas, still, the generation and distribution power in Nigeria is barely "epileptic". This is due to the endemic nature of energy poverty in the country and as a result, not one source will quench the energy thirst (Okonkwo et al., 2021), thus the need for a paradigm shift as a plausible route to the energy transition from fossils to renewable (Figure 2). According to African Development Bank (2011), the instability of electricity supply is by far the most binding constraint to ease of doing business in Nigeria. Looking at the huge revenue, the country derived from the oil and gas industry but has not translated into any meaningful growth and development of the country especially towards stabilizing power (Akuru \& Okoro, 2010). Frankly, the correlation between energy and economic development in Nigeria is termed "paradox" and hence the need to decentralize the power sources to align with renewables to put forward solutions to the dwindling power failure that hibernate the brightest and economic progress of the country.

Research conducted by Elum \& Momodu (2017) revealed that the Niger-Delta region of the country, where the crude oil exploration is taking place with over 11 multinational oil companies, contributed immensely to the global warming with flared gases of about 17 billion cubic meters, including methane (about 12 million tons), carbon dioxide (3.5 million tons) and sulphur dioxide (160 tons) released into the atmosphere. Consequently, decentralizing the energy sector would amount to the tremendous advancement tailored towards improving the general standard of living particularly by lifting the rural dwellers out of

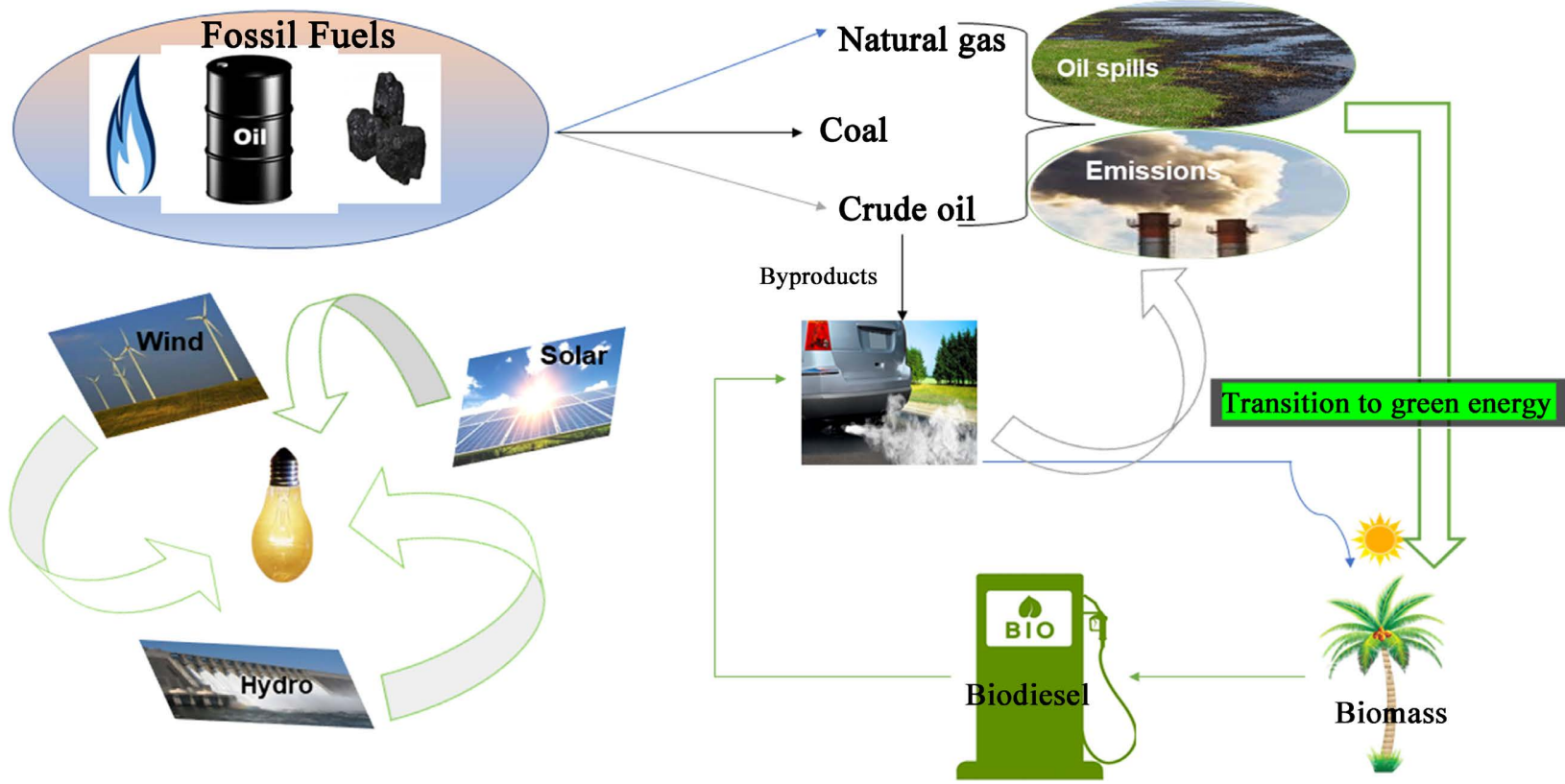

Figure 2. Energy transition chart from fossil fuels to renewable. 
the poverty territory (Adewuyi et al., 2020). This will in the short-term ensure sufficient, efficient, and stable power supply, stimulate a sustainable environment in the medium term, and secure long-term economic development that would attract foreign investment to foster growth and sustainable development while simultaneously satisfying the present national needs without compromising that of the future. Additionally, Elum \& Momodu (2017) reported that climate change is expected to further impact the already limited energy power supply in Nigeria, through impacts on hydroelectric and thermal generation. Lower rainfall in the north, for example, reduces the availability of trees and biomass for conservation and domestic uses respectively, while excessive rainfall in coastal and rainforest zones is also expected to adversely affect power generation, through damage of transmission lines and substation equipment.

\section{Renewable Energy Resource}

Renewable energy is simply energy harnessed from a natural resource that is replenished and non-depleted, which can be obtained from biomass, solar, wind, hydro, and geothermal. ${ }^{47}$ These forms of energy have not only brought about numerous sweeping changes to our world in terms of a better environment but also upgrade the standard of living through improved socio-economic and sustainable development. Today, renewable energy is a leading player in the context of providing affordable, clean and sustainable energy that can fulfil the increasing energy demand worldwide (Vidadili et al., 2017). Therefore, the demand for renewable energy is both environmentally and politically driven and this is further aggravated by the ongoing quest for transition to clean energy that is less potent to GHG emission. According to the latest IEA report, renewable energy demand has risen by $45 \%$ in 2020 despite the challenge posed by COVID-19 pandemic. For instance, countries like the USA, China, Brazil, Argentina, Germany, Australia, Singapore, Indonesia, Malaysia, South Africa, and Kenya are utilizing a significant proportion of renewable in their energy mix especially in electricity generation and transportation (Latif et al., 2021). But unfortunately, despite the growing utilization of renewables globally, production and consumption have not been felt in Nigeria (Emembolu et al., 2016).

However, it is obvious that the lack of sustainability of fossil fuel, paves the way to the need for renewables, as an alternative energy resource that is proficient to satisfy the ever-growing energy demand (Ellabban et al., 2014). In this context, several countries were said to have developed their renewable energy industry, these include Brazil (bioethanol), Germany (offshore and onshore wind; biogas), Australia (wind; solar), Malaysia and Indonesia (biodiesel), Singapore (floating solar system) Kenya (geothermal; solar), South Africa (solar; nuclear power), etc. Therefore, the transition to renewable energy resources in Nigeria is long overdue considering how sister African countries are striving to flow with the contemporary technology (Taylor, 2008). The renewable energy market is growing exponentially across the globe and is foreseen to take the lead 
in the future energy sphere. On top of that, National Renewable Energy Plan, (2020) revealed that renewable energy technology contributes to the growth of energy dependence, cut down the importation of crude oil, promote resource conservation, protect the environment, and create job opportunities through improved social and economic prosperity that foster growth and development of both rural and urban economies (Yusuf et al., 2011). Conversely, renewable energy has its own share of weakness in that not all forms of renewable energy are economically viable.

\subsection{Hydropower}

The use of hydropower plants to generate electricity in Nigeria has been in existence for decades and is relatively the country's main source of power ( $\mathrm{Li}$ et al., 2013). Thus, the use of hydroelectricity in Nigeria would be largely driven due to the abundant water resources and this made the country build some hydropower infrastructures at Mambila, Kainji, Jebba, and Shiroro, but the functionality of these hydro plants remained shoddy (Iwayemi, 2008). Interestingly, nature being part of the environment becomes economically gainful by boosting the economy from hydropower plants via electricity generation to underpin industrial development, derive revenue, and provide employment opportunities (Crețan \& Vesalon, 2017). Simply, energy generated from water is said to be the most widely used form of renewable energy having a very low-carbon emission rate. Small scale hydro or micro-hydro power has been an increasingly popular alternative energy source, especially in remote areas where other power sources are not viable (Oyedepo et al., 2019).

\subsection{Biomass}

Bioenergy-derived form of renewables has been of keen interest, considering the abundance of biomass globally. Biomass is a type of renewable energy that is obtained from living and dead biological materials, used as biofuel for domestic and industrial purposes (Giwa et al., 2017). Some of these materials include plant matter such as dead trees, branches, yard clippings, and wood chips, etc. Others include animal matter and biodegradable wastes, all of which exist abundantly in Nigeria. This form of renewable energy provides numerous opportunities such as improved agricultural activities, creating employment, boosting local economies, reducing over-dependence on imported oil, and serving as a tool towards achieving a circular economy by redirecting waste to value-added products (Abdullah et al., 2019). While there is no commercial waste-to-energy plant, the technology for waste to bio-energy generation, is yet onboard in Nigeria (Nwankwoala, 2012). Therefore, green energy from biomass is strategic in the context of the current energy scenario and will continue to contribute unabatedly towards meeting global energy security. Bioethanol and biodiesel are the two promising types of biofuels that have the potential to reduce particulate emissions in the compression-ignition engine. Both of which have passed the 
EPA Tier I and Tier II Health Effects testing requirements of clean Air Act Amendments of 1990 (Yuan et al., 2009). However, the argument of food versus fuel competition for the feedstocks used in producing these biofuels often declined their production rate. But recently, the production of bioethanol and biodiesel have shifted from biobased feedstocks to algal and industrial waste $\mathrm{CO}_{2}$ often addressed as third and fourth generation feedstocks respectively (Gouveia \& Oliveira, 2009).

\subsection{Solar}

According to Sarralde et al. (2015) the solar industry is growing rapidly with a projection of leading the installation gadgets. But according to climate scored 2021, Nigeria is not doing enough in terms of harnessing the huge potentials of solar, with nothing to write home about as per production is concerned. In the same vein, the total energy derived from hydro and solar is just only 0.35 and $0.001 \%$ respectively and this is not surprised as the country relied heavily on exported oil as the main energy source (Good et al., 2014). Therefore, the derivation of energy from solar would go a long way in addressing the country's power failure for decades. Similarly, Overland et al. (2019) reported that Nigeria is ranked 149 out 156 countries with enabling geographical atmospheres such as abundant biomass, sufficient solar rays that are present all year round, and a large stream of rivers and dams, yet the transition to green energy is not fully embraced. Thus, the deployment of solar plants would complement other conventional and renewable energy technologies in the generation and servicing of electricity to the grid. Moreover, studies conducted by Good et al. (2014) indicates that if only $1 \%$ of Nigeria's landmass is used as a solar farm, that would produce about 207,000 gigawatt of electricity per year which is more than enough to satisfy Nigeria's energy requirements by scaling up access to electricity and support local productivity. More recently, to bridge the issue of space for solar farms, countries like Singapore were opting to float solar farms in a bid to expand the generation of electricity from solar energy.

In this context, the advent of the COVID-19 pandemic prompted the Nigerian government to come up with a bouncing back plan to harness the potentials of sunlight energy as an emerging route to sustainable power infrastructure (Economic Sustainability Committee, 2020). Prior to this, Nigeria has proposed a plan called "Energy for all" which seeks to provide solar energy to about five million households that are not presently on the natural grid (Owadano, 2020). A project believed to minimize impacts of GHG emissions through reduction of combustion emissions, while simultaneously granting access to electricity, water supply and supporting small-scale businesses. This will open a window for sustainable socio-economic development and subsequently reduce the level of errant poverty, particularly among rural dwellers. But unfortunately, the project was not justly executed as not many were fully aware of the project (Akuru \& Okoro, 2010). Unfortunately, despite the popular use of solar energy in urban 
areas, its implementation requires all-inclusive urban planning especially the synergy between solar energy and urban morphology (Sarralde et al., 2015). Moreover, the hazardous substances accompanied by the production process and short life span of the solar module are foreseen to foster serious environmental and economic consequences (Gomesh et al., 2013).

\subsection{Wind and Geothermal Energy}

These forms of renewable energy are relatively scarce in most African countries, for which Nigeria is not an exception. Despite being uncommon, but wind energy is popular and graciously utilized both on-shore and off-shore in Germany and other European countries (Okonkwo et al., 2021). Wind power involves the conversion of wind to energy by turbines into a form of electricity or mechanical energy. Large-scale wind farms are connected to the local power transmission network with small turbines to generate electricity (Brimmo et al., 2017). Historically, it has been used directly to propel sailing ships or converted into mechanical energy for pumping water or grinding grain, but the principal application of wind power today is the generation of electricity (Abdulkadir et al., 2018). However, in Nigeria wind energy is yet to be fully developed despite the enabling sites for both off and onshore wind farming as highlighted in Renewable Energy Master Plan, an effort was sometimes made to construct two wind farms in Plateau and Katsina states in the northern part of the country. Unfortunately, these projects were abandoned by the successive governments in those states (Ngene et al., 2016). However, energy derived from geothermal comes from the sub-surface of the earth, water, or steam, which usually convey the geothermal to the earth's surface. Geothermal energy production is an efficient way of harnessing renewable energy from the earth by natural processes. It can be done on a small scale to cater to residential demand using a geothermal heat pump, or for huge energy production via a geothermal power plant for largescale use (Bertani, 2016). But location specificity, environmental side effects during digging, and cost are some of the major barriers that limit wider utilization of this type of renewable energy as its presence is barely close to none in Nigeria.

\section{Conclusion}

In conclusion, energy regeneration and a safer environment are directly related to all aspects of sustainable developments. Thus, energy thirst and excessive GHG emissions heightened by burning fossils in Nigeria are of great concern, as these pose threats to the ecosystem, economy, and public health. However, some of the environmental and climate induced challenges are, coastal erosion with untold damage in South-East, propelling severe threat to inhabitants; desertification and rising heat waves in many Northern states, thereby discomforting humans and inhibiting successful farming activities; oils spillage and gas flaring in the South-South zone due to oil exploration activities, resulting in land and wa- 
ter pollution, etc. Therefore, the Nigerian government needs to urgently invest in renewable energy, as a first step to achieving the paradigm shift for an energy transition from fossil-based fuels to a more contemporary and eco-friendly renewable energy. This will foster a more diversified and decentralized energysupply pattern, boost economic activities, accelerate sustainable developments, support mitigation and adaptation strategies against climate change. Additionally, afforestation should be encouraged through the planting of many trees to support lifelong protection and biodiversity conservation. This will help to clamp down more $\mathrm{CO}_{2}$ emissions that heightened the catastrophic effects of climate change and global warming, particularly in the northern states.

\section{Acknowledgements}

The authors are thankful to PTDF-Nigeria, for granting them a scholarship, to pursue postgraduate studies.

\section{Conflicts of Interest}

The authors declare no conflicts of interest regarding the publication of this paper.

\section{References}

Abali, H. W., Etebu, O. M., \& Leton, T. G. (2018). Seasonal Particulate Pollution in Port Harcourt Nigeria. Journal of Environment Pollution and Human Health, 6, 20-25. https://doi.org/10.12691/jephh-6-1-3

Abdulkadir, A., Maryam Lawal, A., \& Muhammad, T. I. (2018). Climate Change and Its Implications on Human Existence in Nigeria: A Review. Bayero Journal of Pure and Applied Sciences, 10, 152-158. https://doi.org/10.4314/bajopas.v10i2.26

Abdullah, B., Syed Muhammad, S. A. F., Shokravi, Z., Ismail, S., Kassim, K. A., Mahmood, A. N., \& Aziz, M. M. A. (2019). Fourth Generation Biofuel: A Review on Risks and Mitigation Strategies. Renewable and Sustainable Energy Reviews, 107, 37-50. https://doi.org/10.1016/j.rser.2019.02.018

Adamu, H., Umar, Y. A., Akanang, H., \& Sabo, A. (2021). Evaluation of Carbon Sequestration Potential of Soils-What Is Missing? Journal of Geoscience and Environment Protection, 9, 39-47. https://doi.org/10.4236/gep.2021.98003

Adewuyi, O. B., Kiptoo, M. K., Afolayan, A. F., Amara, T., Alawode, O. I., \& Senjyu, T. (2020). Challenges and Prospects of Nigeria's Sustainable Energy Transition with Lessons from Other Countries' Experiences. Energy Reports, 6, 993-1009.

https://doi.org/10.1016/j.egyr.2020.04.022

African Development Bank (2011). Private Sector Development as an Engine of Africa's Economic Development (pp. 117-166).

https://www.afdb.org/sites/default/files/documents/publications/african_development_ report_2011.pdf

Agarwal, A. K. (2007). Biofuels (Alcohols and Biodiesel) Applications as Fuels for Internal Combustion Engines. Progress in Energy and Combustion Science, 33, 233-271. https://doi.org/10.1016/j.pecs.2006.08.003

Akande, A., Costa, A. C., Mateu, J., \& Henriques, R. (2017). Geospatial Analysis of Extreme Weather Events in Nigeria (1985-2015) Using Self-Organizing Maps. Advances 
in Meteorology, 2017, Article ID: 8576150. https://doi.org/10.1155/2017/8576150

Akuru, U. B., \& Okoro, O. I. (2010). Renewable Energy Investment in Nigeria: A Review of the Renewable Energy Master Plan. In 2010 IEEE International Energy Conference (pp. 166-171). IEEE. https://doi.org/10.1109/ENERGYCON.2010.5771668

Association, W. B. (2020). Global Bioenergy Statistics. World Bioenergy Association, http://www.worldbioenergy.org/uploads/201210 WBA GBS 2020.pdf

Bertani, R. (2016). Geothermal Power Generation in the World 2010-2014 Update Report. Geothermics, 60, 31-43. https://doi.org/10.1016/j.geothermics.2015.11.003

Brimmo, A. T., Sodiq, A., Sofela, S., \& Kolo, I. (2017). Sustainable Energy Development in Nigeria: Wind, Hydropower, Geothermal and Nuclear. Renewable and Sustainable Energy Reviews, 74, 474-490.

Chikwe, T. N., \& Ogbole, S. N. (2019). Remediation of Simulated Oil Contaminated Sites Using Shells of Clams and Oyster-Total Petroleum Hydrocarbons of Simulated Oil Contaminated Sites, before and after Remediation. Nigerian Journal of Chemical Research, 24, 57-67.

Coster, A. S., \& Adeoti, A. I. (2015). Economic Effects of Climate Change on Maize Production and Farmers' Adaptation Strategies in Nigeria: A Ricardian Approach. Journal of Agricultural Science, 7, 67-84. https://doi.org/10.5539/jas.v7n5p67

Crețan, R., \& Vesalon, L. (2017). The Political Economy of Hydropower in the Communist Space: Iron Gates Revisited. Tijdschrift Voor Economische En Sociale Geografie, 108, 688-701. https://doi.org/10.1111/tesg.12247

Dinar, A., Hassan, R., Mendelsohn, R., \& Benhin, J. (2012). Climate Change and Agriculture in Africa: Impact Assessment and Adaptation Strategies. Routledge. https://doi.org/10.4324/9781849770767

Ebele, N., \& Emodi, N. (2016). Climate Change and Its Impact in Nigerian Economy. Journal of Scientific Research and Reports, 10, 1-13.

Economic Sustainability Committee (2020). Bouncing Bank: Nigeria Economic Sustainability Plan. Economic Sustainability Committee, 76 p.

Efe, S. I., \& Weli, V. E. (2015). Economic Impact of Climate Change in Port Harcourt, Nigeria. Open Journal of Social Sciences, 3, 57-68.

https://doi.org/10.4236/jss.2015.33012

Eleri, E. O., Onuvae, P., \& Ugwu, O. (2013). Low-Carbon Energy Development in Nigeria (pp. 2-24). International Institute for Environment and Development. https://pubs.iied.org/sites/default/files/pdfs/migrate/G03555.pdf

Ellabban, O., Abu-Rub, H., \& Blaabjerg, F. (2014). Renewable Energy Resources: Current Status, Future Prospects and Their Enabling Technology. Renewable and Sustainable Energy Reviews, 39, 748-764. https://doi.org/10.1016/j.rser.2014.07.113

Elum, Z. A., \& Momodu, A. S. (2017). Climate Change Mitigation and Renewable Energy for Sustainable Development in Nigeria: A Discourse Approach. Renewable and Sustainable Energy Reviews, 76, 72-80. https://doi.org/10.1016/j.rser.2017.03.040

Emembolu, L. N., Onukwuli, D. O., \& Nwabanne, J. T. (2016). Determination of Flow Properties of Refined Cotton Seed Oil Biodiesel. Journal of Scientific and Engineering Research, 3, 131-143.

https://www.researchgate.net/publication/335107820_Determination_of_Flow_Propert ies_of_Refined_Cotton_Seed_Oil_Biodiesel

Giwa, A., Alabi, A., Yusuf, A., \& Olukan, T. (2017). A Comprehensive Review on Biomass and Solar Energy for Sustainable Energy Generation in Nigeria. Renewable and Sustainable Energy Reviews, 69, 620-641. https://doi.org/10.1016/j.rser.2016.11.160 
Gomesh, N., Daut, I., Irwanto, M., Irwan, Y. M., \& Fitra, M. (2013). Study on Malaysian's Perspective towards Renewable Energy Mainly on Solar Energy. Energy Procedia, 36, 303-312. https://doi.org/10.1016/j.egypro.2013.07.035

Good, C. S., Lobaccaro, G., \& Hårklau, S. (2014). Optimization of Solar Energy Potential for Buildings in Urban Areas-A Norwegian Case Study. Energy Procedia, 58, 166-171. https://doi.org/10.1016/j.egypro.2014.10.424

Gouveia, L., \& Oliveira, A. C. (2009). Microalgae as a Raw Material for Biofuels Production. Journal of Industrial Microbiology and Biotechnology, 36, 269-274. https://doi.org/10.1007/s10295-008-0495-6

Haider, H. (2019). Climate Change in Nigeria: Impacts and Responses. K4D Helpdesk Report, 38 p. http://opendocs.ids.ac.uk/opendocs/handle/20.500.12413/14761

Idowu, A. A., Ayoola, S. O., Opele, A. I., \& Ikenweiwe, N. B. (2011). Impact of Climate Change in Nigeria. Iranica Journal of Energy \& Environment, 2, 145-152. https://www.researchgate.net/publication/228459699

IRENA (2019). Hydrogen: a Renewable Energy Perspective. IRENA. https://irena.org/publications/2019/Sep/Hydrogen-A-renewable-energy-perspective

Iwayemi, A. (2008). Investment in Electricity Generation and Transmission in Nigeria: Issues and Options. International Association for Energy Economics. https://www.iaee.org/en/publications/newsletterdl.aspx?id=38

Kailasam, K. (2006). Community Water Quality Monitoring Programme in Malaysia. Community Water Quality Monitoring Programme in Malaysia, $6 \mathrm{p}$.

Latif, S. N. A., Chiong, M. S., Rajoo, S., Takada, A., Chun, Y. Y., Tahara, K., \& Ikegami, Y. (2021). The Trend and Status of Energy Resources and Greenhouse Gas Emissions in the Malaysia Power Generation Mix. Energies, 14, Article No. 2200.

https://doi.org/10.3390/en14082200

Lee, J. T., \& Callaway, D. S. (2018). The Cost of Reliability in Decentralized Solar Power Systems in Sub-Saharan Africa. Nature Energy, 3, 960-968.

https://doi.org/10.1038/s41560-018-0240-y

Li, K., Zhu, C., Wu, L., \& Huang, L. (2013). Problems Caused by the Three Gorges Dam Construction in the Yangtze River Basin: A Review. Environmental Reviews, 21, 127-135. https://doi.org/10.1139/er-2012-0051

Meyer, S., Laurence, H., Bart, D., Lucie, M., \& Kevin, M. (2018). Capturing the Multifaceted Nature of Energy Poverty: Lessons from Belgium. Energy Research and Social Science, 40, 273-283. https://doi.org/10.1016/j.erss.2018.01.017

Mofijur, M., Mahlia, T. M. I., Silitonga, A. S., Ong, H. C., Silakhori, M., Hasan, M. H., Putra, N., \& Ashrafur Rahman, S. M. (2019). Phase Change Materials (PCM) for Solar Energy Usages and Storage: An Overview. Energies, 12, Article No. 3167. https://doi.org/10.3390/en12163167

Ngene, S., Tota-Maharaj, K., Eke, P., \& Hills, C. (2016). Environmental and Economic Impacts of Crude Oil and Natural Gas Production in Developing Countries. International Journal of Economy, Energy and Environment, 1, 64-73.

Nicholls, R. J. (2004). Coastal Flooding and Wetland Loss in the 21st Century: Changes under the SRES Climate and Socio-Economic Scenarios. Global Environmental Change, 14, 69-86. https://doi.org/10.1016/j.gloenvcha.2003.10.007

Nwankwoala, H. (2012). Case Studies on Coastal Wetlands and Water Resources in Nigeria. European Journal of Sustainable Development, 1, 113. https://doi.org/10.14207/ejsd.2012.v1n2p113

Obiakalaije, U. M., Makinde, O. A., \& Amakoromo, E. R. (2015). Bioremediation of 
Crude Oil Polluted Soil Using Animal Waste. International Journal of Environmental Bioremediation \& Biodegradation, 3, 79-85. https://doi.org/10.12691/ijebb-3-3-2

Ofosu-Peasah, G., Ofosu Antwi, E., \& Blyth, W. (2021). Factors Characterising Energy Security in West Africa: An Integrative Review of the Literature. Renewable and Sustainable Energy Reviews, 148, Article ID: 111259.

https://doi.org/10.1016/j.rser.2021.111259

Oji, S., \& Adamu, H. (2021). Air Pollution Exposure Mapping by GIS in Kano Metropolitan Area. Pollution, 7, 101-112. https://doi.org/10.22059/poll.2020.304945.838

Okonkwo, C. C., Edoziuno, F. O., Adediran, A. A., Ibitogbe, E. M., Mahamood, R., \& Akinlabi, E. T. (2021). Renewable Energy in Nigeria: Potentials and Challenges. Journal of Southwest Jiaotong University, 56, 528-539. https://doi.org/10.35741/issn.0258-2724.56.3.44

Okundamiya, M. S., Emagbetere, J. O., \& Ogujor, E. A. (2014). Assessment of Renewable Energy Technology and a Case of Sustainable Energy in Mobile Telecommunication Sector. The Scientific World Journal, 2014, Article ID: 947281. https://doi.org/10.1155/2014/947281

Onah, N. G., Alphonsus, N. A., \& Ekenedilichukwu, E. (2016). Mitigating Climate Change in Nigeria: African Traditional Religious Values in Focus. Mediterranean Journal of Social Sciences, 7, 299-307. https://doi.org/10.5901/mjss.2016.v7n6p299

Oseni, M. O. (2011). An Analysis of the Power Sector Performance in Nigeria. Renewable and Sustainable Energy Reviews, 15, 4765-4774. https://doi.org/10.1016/j.rser.2011.07.075

Overland, I., Bazilian, M., Ilimbek Uulu, T., Vakulchuk, R., \& Westphal, K. (2019). The GeGaLo Index: Geopolitical Gains and Losses after Energy Transition. Energy Strategy Reviews, 26, Article ID: 100406. https://doi.org/10.1016/j.esr.2019.100406

Owadano, Y. (2020). Renewable Energy Deployment in Transport Sector. Trends in the Sciences, 25, 138-141. https://doi.org/10.5363/tits.25.1_38

Oyedepo, S. O. (2012). On Energy for Sustainable Development in Nigeria. Renewable and Sustainable Energy Reviews, 16, 2583-2598.

https://doi.org/10.1016/j.rser.2012.02.010

Oyedepo, S. O. (2014). Towards Achieving Energy for Sustainable Development in Nigeria. Renewable and Sustainable Energy Reviews, 34, 255-272.

https://doi.org/10.1016/j.rser.2014.03.019

Oyedepo, S. O., Uwoghiren, T., Babalola, P. O., Nwanya, S. C., Kilanko, O., Leramo, R. O., Aworinde, A. K., Adekeye, T., Oyebanji, J. A., \& Abidakun, O. A. (2019). Assessment of Decentralized Electricity Production from Hybrid Renewable Energy Sources for Sustainable Energy Development in Nigeria. Open Engineering, 9, 72-89.

https://doi.org/10.1515/eng-2019-0009

Qurashi, M. M., \& Hussain, T. (2005). Renewable Energy Technologies for Developing Countries Now and to 2023. Publications of the Islamic Educational, Scientific and Cultural Organization-ISESCO.

http://www.solar-academy.com/menuis/Renewable-Energy-Technologies-for-Developi ng-Countries184122.pdf

Sandu, S., Yang, M., Mahlia, T. M. I., Wongsapai, W., Ong, H. C., Putra, N., \& Ashrafur Rahman, S. M. (2019). Energy-Related $\mathrm{CO}_{2}$ Emissions Growth in ASEAN Countries: Trends, Drivers and Policy Implications. Energies, 12, Article No. 4650. https://doi.org/10.3390/en12244650

Sarralde, J. J., Quinn, D. J., Wiesmann, D., \& Steemers, K. (2015). Solar Energy and Urban 
Morphology: Scenarios for Increasing the Renewable Energy Potential of Neighbourhoods in London. Renewable Energy, 73, 10-17. https://doi.org/10.1016/j.renene.2014.06.028

Shaaban, M., \& Petinrin, J. O. (2014). Renewable Energy Potentials in Nigeria: Meeting Rural Energy Needs. Renewable and Sustainable Energy Reviews, 29, 72-84. https://doi.org/10.1016/j.rser.2013.08.078

Statista (2021). Population of Nigeria in Selected Years between 1950 and 2021. https://www.statista.com/statistics/1122838/population-of-nigeria/

Taylor, G. (2008). Biofuels and the Biorefinery Concept. Energy Policy, 36, 4406-4409. https://doi.org/10.1016/j.enpol.2008.09.069

Tick Hui, O., Hasanuzzaman, M., Selvaraj, J., Teo, S. C., \& Chua, S. C. (2018). Energy Policy and Alternative Energy in Malaysia: Issues and Challenges for Sustainable Growth-An Update. Renewable and Sustainable Energy Reviews, 81, 3021-3031. https://doi.org/10.1016/j.rser.2017.06.112

Vidadili, N., Suleymanov, E., Bulut, C., \& Mahmudlu, C. (2017). Transition to Renewable Energy and Sustainable Energy Development in Azerbaijan. Renewable and Sustainable Energy Reviews, 80, 1153-1161. https://doi.org/10.1016/j.rser.2017.05.168

Vine, E. (2008). Breaking down the Silos: The Integration of Energy Efficiency, Renewable Energy, Demand Response and Climate Change. Energy Efficiency, 1, 49-63. https://doi.org/10.1007/s12053-008-9004-Z

Yuan, W., Hansen, A. C., \& Zhang, Q. (2009). Predicting the Temperature Dependent Viscosity of Biodiesel Fuels. Fuel, 88, 1120-1126. https://doi.org/10.1016/j.fuel.2008.11.011

Yusuf, N. N. A. N., Kamarudin, S. K., \& Yaakub, Z. (2011). Overview on the Current Trends in Biodiesel Production. Energy Conversion and Management, 52, 2741-2751. https://doi.org/10.1016/j.enconman.2010.12.004

\section{List of Abbreviations}

CFCs Chlorofluorocarbons;

$\mathrm{CO}_{2}$ Carbon dioxide;

$\mathrm{CO}$ Carbon monoxide;

EIA Environmental impact assessment;

EPA Environmental protection agency;

GHG Greenhouse gases;

USA United States of America;

UN United Nation;

SDGs Sustainable development goals. 